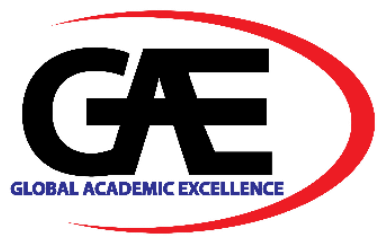

\title{
ANALYSIS OF HALAL ASSURANCE MANAGEMENT ON IMPORTED FOOD PRODUCTS IN MALAYSIA
}

\author{
Mohd Zaid Daud ${ }^{1}$, Nur Farhani Zarmani ${ }^{2 *}$, Mohd Amzari Tumiran ${ }^{3}$ \\ 1 Academy of Contemporary Islamic Studies, Universiti Teknologi MARA, Malaysia \\ Email: mohdzaid@uitm.edu.my \\ 2 Academy of Contemporary Islamic Studies, Universiti Teknologi MARA, Malaysia \\ Email: nurfarhani@uitm.edu.my \\ 3 Academy of Contemporary Islamic Studies, Universiti Teknologi MARA, Malaysia \\ Email: amzari92@uitm.edu.my \\ Corresponding Author
}

\section{Article Info:}

\section{Article history:}

Received date:30.04.2021

Revised date: 21.06.2021

Accepted date: 26.07.2021

Published date: 15.09.2021

\section{To cite this document:}

Daud, M. Z., Zarmani, N. F., \& Tumiran, M. A. (2021). Analysis of Halal Assurance Management on Imported Food Products in Malaysia. International Journal of Halal Ecosystem and Management Practices, 1 (1), 08-19.

DOI: 10.35631/IJHEMP.11002.

This work is licensed under $\underline{\text { CC BY } 4.0}$ (ㅇ)(1)

\begin{abstract}
:
The entry of imported food products into Malaysia is on an increasing trend. However, the halal monitoring and enforcement system's weakness has given room to irresponsible entrepreneurs not conforming to the manual procedure for Malaysia's halal certification. This weakness gives rise to various malpractices, including the smuggling activities, forgery of international halal logo and certificate, and attempts of contaminating with nonhalal ingredients in the food processor. The management of the halal assurance system on imported food products in Malaysia is carried out by JAKIM and other government agencies such as the Ministry of Domestic Trade and Consumers Affairs (KPDNHEP), Ministry of Health (MOH), Food Safety Information System of Malaysia (FOSIM), Royal Malaysian Customs Department, Malaysian Quarantine and Inspection Services (MAQIS), Department of Veterinary Services (DVS) and Local Authority. The monitoring and enforcement are based on Manual Procedure for Malaysian Halal Certification (MPPHM), Malaysian Standard (MS), Trade Descriptions Act 2011 (TDA 2011), and other related directives. Therefore, despite many agencies contributing to this matter, an analysis of Halal Assurance Management on Imported Food Products in Malaysia is crucially needed to manage halal monitoring and enforcement. This study may contribute to halal management in Malaysia to develop a systematic halal assurance management system, particularly for imported food products. This study can provide a guideline for imported food product entrepreneurs in conforming to the act, regulations, procedure, and standard specified by the authorities. The implication of this study also benefits the consumers. They will become more confident in the halal status of imported food products and entrust the Malaysian management of halal assurance in the monitoring and enforcement system.
\end{abstract}


Keywords:

Halal; Assurance; Food Products; Import; Management

\section{Introduction}

The entry of imported food products into Malaysia is on the increasing number for the past ten years. According to Malaysia External Trade Development Corporation (MATRADE, 2020), every year, the imported food product into Malaysia is always in the top ten major import products. The World Integrated Trade Solutions (WITS, 2018) stated, from 2010 to 2018, Malaysian Imported food products have increased a good trend over more than five years. The recent data have shown the demand for imported processed food products from 2018 to 2019 increased to 2.4\%, from RM19.95bil to RM20.28bil for the current year. About this demand from the consumers, a complete and robust management system ensures halal assurance on imported food products is indispensable to avoid any causes of unforeseen issues.

Unfortunately, the recent news has shocked Malaysia when the authorities have recently busted and seized 1,500 tons of frozen meat worth RM30mil smuggled from Ukraine, Brazil, Argentina, and China and then repackaged it with the fake halal logo (Farhan et al., 2021, Sim et al., 2020, Ying, 2020). This unforeseen issue occurred on cartel meat at a warehouse in Senai, Johor, which has been operating for a few years, allegedly used the warehouse as a location to make fake labels and stamps, which pasted on the packages of meat before being sold in the local market. In addition, the cartel managed to keep this operation secretly by disguising itself as a frozen meat supplier.

Thus, the recent unearthing of a cartel smuggling in frozen meat indicates an urgent need to strengthen the halal control standards (Farhan et al., 2021) and increase the monitoring visit of the authority's bodies at all entrance gates into the country (Azdee, 2020). It also shows the lack of management control on ensuring the safety and status of halal on imported food products.

Therefore, some non-Government organizations urged the Malaysian Anti-Corruption Commission (MACC) to conduct a thorough investigation into a meat cartel that smuggled uncertified frozen meat using fake halal labels (Bernama, 2020). These demands include revealing the identity of the brand used by the cartel as unauthorized meat, investigating the cause of non recalled meats that have been distributed to the market and analyzing the action taken on raids in other states (Ying, 2020). However, to date, the Johor government upholds the actions in formulating a framework to be taken on the meat cartel as it is a serious issue concerning Muslim Foods. This involves the State Islamic Religious Department (JAINJ) and all relevant departments, including representatives of all ports in the state (Bernama, 2020).

Due to the above issue, this study will analyze the management of the halal assurance system on imported food products in Malaysia

\section{Management of Imported Food Product in Malaysia}

The management of the assurance system on imported food products in Malaysia is carried out by the Ministry of Health $(\mathrm{MOH})$ under the Food Safety Quality Division (FSQD). This management of import and export also has been contributed with many government authorities 
and agencies such as the Ministry of Domestic Trade and Consumers Affairs (KPDNHEP), Food Safety Information System of Malaysia (FOSIM), Royal Malaysian Customs Department, Malaysian Quarantine and Inspection Services (MAQIS), Department of Veterinary Services (DVS), Local Authority and also the Department of Islamic Development Malaysia (JAKIM) for the halal imported food products.

\section{Types of Imported Food Products}

According to Noor Azmi (2015), imported food products in Malaysia are classified into three categories, depending on their certification. The first type is an imported food product that is not declared as a halal product. This means the product is imported to Malaysia without any halal logo or halal certification that indicates it is a halal product. The second type is an imported food product that uses JAKIM halal logo and certificate. Even this product is not produced in Malaysia, JAKIM can certify the product and give them to use the halal logo and certification. The third type is an imported food product that uses JAKIM recognized certification bodies (CB) from foreign countries called Foreign Halal Certification Bodies (FHCB). This product uses the halal logo and the halal certification from their country's government or the country's non-government organization (NGO's).

Thus, these importations of food products are omitted under the Food Act 1983 and its regulations and Trade Description Act 2011.

\section{The Importation of Foods under The Control of The Food Act 1983 and Food Regulations 1985}

Generally, the importation of food in Malaysia is not explicitly stated on halal matters, but it contributes to the safety aspect. The importation of foods under the control of the Food Act 1983 and its regulations are not subjected to import permits. Instead, the command is just a food approval by the Ministry of Health Malaysia (MOH) at the entrance through the Food Safety Information System of Malaysia (FOSIM). The control's main objective is to ensure the food imported into the country is safe and comply with all provisions of the Food Act 1983 and its regulations. The Imported food control activities carried out at the country's entrance include the inspection and sampling of food consignments and enforcement activities such as detention, withdrawal, rejection, prosecution, and destruction of consignments that violate the food laws. This approval procedure can be divided into two main phases: before the importation and during the importation.

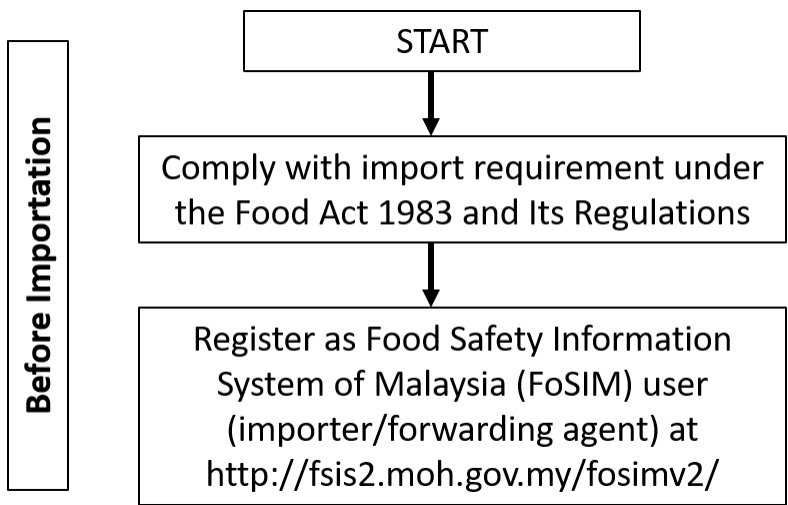

Figure 1: Flow Chart of Food Import Procedures for Importers and Agents (Before Importation) 


\section{Before Importation of The Foods Products}

Before the importation, all the importers of food products must ensure they have complied with the Malaysian Food Act 1983 and its regulations. In addition, they must ensure the food does not fall under the jurisdiction of the National Pharmaceutical Regulatory Agency (NPRA), Ministry of Health, Malaysia (FSQD, 2020). This is because pharmaceutical products are not considered food products due to drugs or any related under the control of NPRA. Thus, all the importers must identify whether their food requires additional documentation when imported, such as a health certificate, certificate of analysis, license, or any related documents.

After fulfilling the first procedure, the importer and forwarding agent (customs broker) must register their food products with the Food Safety Information System of Malaysia (FOSIM). FOSIM is an intelligent web-based information system developed to improve the food safety surveillance management system, besides ensuring the food imported to Malaysia is safe to consume. This system is linked to the Royal Malaysian Customs Department system known as the Customs Information System (CIS), allowing importers, shipping agents, and authorized officers to electronically manage food import activities using a risk-based approach to determine the hazards of imported food products (FOSIM, 2020).

During this procedure, the importers must fulfil some requirements if their product is specifically on the infant food or considered a food that indicates through modern technology (FSQD, 2020). The importers with the infant foods shall adhere to the Code of Ethics for the Marketing of Infant Food and Related Product 2008 governed by the Malaysian Nutrition Department under the Ministry of Health. For food or ingredients obtained through modern biotechnology, the foods must gain approval by the Ministry of Natural Resource and Environment, Malaysia (NRE) before importation is allowed. Besides, these products must comply with labelling requirements for food and food ingredients obtained through modern biotechnology as stipulated under the Food Regulations 1985 (FSQD, 2020).

Furthermore, particular imported food also may require such as import permits or licenses or other requirements from other government agencies. For example, for products related to the agriculture and agro-based industry, the importers must have import permits or licenses from the Department of Quarantine and Inspection Services Malaysia (MAQIS) under the Ministry of Agriculture and Argo-based Industry (MOA). 


\section{During Importation of The Foods Products}

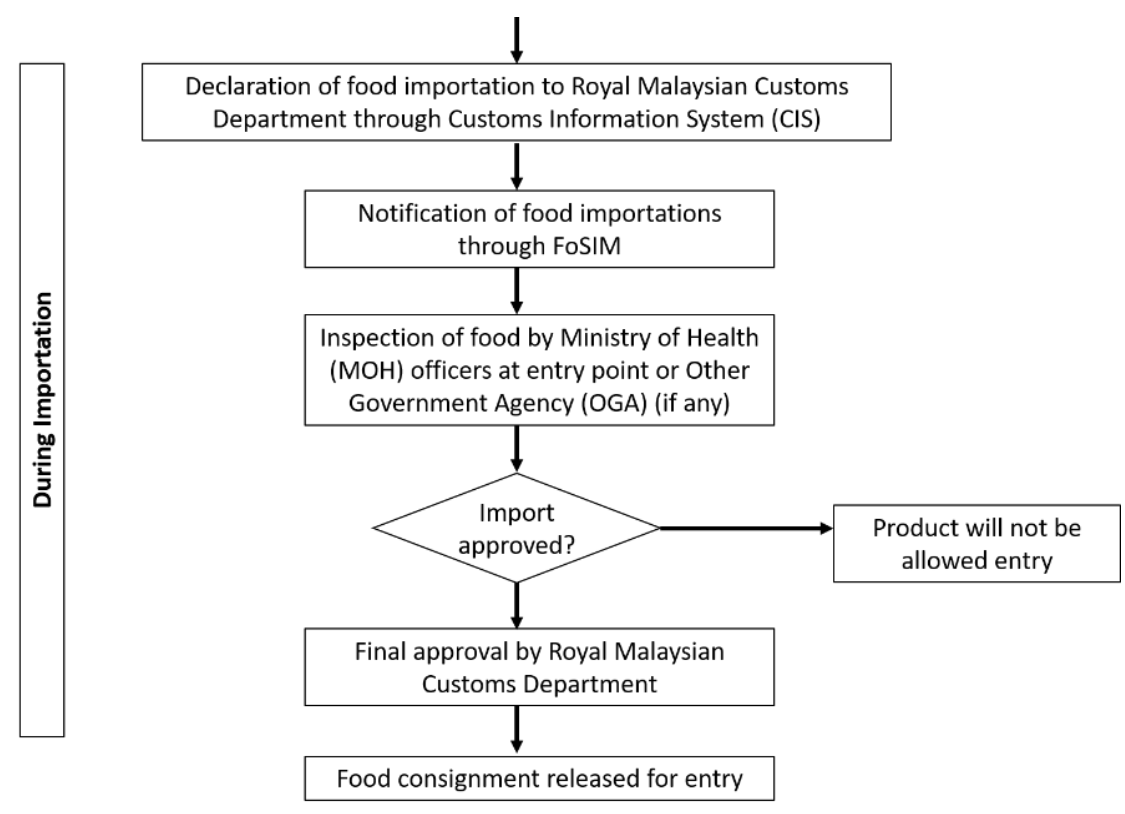

Figure 2: Flow Chart of Food Import Procedures for Importers and Agents (During Importation)

Source: (Food Safety Quality Division)

Based on figure 2 above, this is the approval procedure during the importers' importation after the importers have fulfilled the requirements before entering the country's entrance. Several steps can be measured before the imported food products are released to the country's entry point during importation.

\section{Clearance of Imported Food Consignment via FOSIM}

Upon the arrival of the food consignment at the entry point, the forwarding agent known as the customs broker will declare the importation foods to the Royal Malaysian Customs Department via electronic and transferred them to the FOSIM system. Upon this process, the forwarding agent will use the updated declaration and fill in the essential information required by the system to generate an automatic examination level.

\section{Inspection of Imported Food Product at The Entry Points}

After the clearance of food consignment by the Malaysian Customs Department, there are six inspection levels to determine the risk of the food. It depends on the condition of imported food products. The levels are stated under the Food Safety Quality Division Malaysia (FSQD, 2020).

Level 1 (Unconditional Automatic Release), where the food consignment is given an automatic release.

Level 2 (Specific Document Inspection), the Authorizing Officer at the entrance must examine all relevant documents ( $\mathrm{HC} / \mathrm{CoA} /$ License) before issuing the release.

Level 3 (Risk-Based Monitoring), where inspections are mandatory, and food samples may be taken for laboratory analysis.

Level.4(Surveillance Surveillance), where inspection and sampling are mandatory. The consignment was released after sampling was carried out. 
Level 5 (Hold, Test and Release), inspection and sampling must be done. The consignment is detained after the sampling is carried out, and it will be released after the analysis results comply with the Food Act 1983 and the Food Regulations 1985.

Level 6 (Automatic Rejection), where the system automatically rejects the consignment of the food products involved.

Also, if the importation of the food is for research purposes, food for exhibition purposes, food is explicitly intended for critically ill patients through hospital application, private use, gifts, and food with special approval from the minister, the confirmation letter of approval is needed.

On this matter, any imported foods that are found not to comply with the Food Act 1983 and its regulations will be denied at the entry level or re-exported to its region or other countries that can accept it. In other cases, if the imported food has entered the country, a Product Withdrawal Notice will be issued. For the case of Level Five (5), the imported foods will be resistant, test and release for upcoming subsequent food consignments from the same exporter. Other than that, the imported foods will be disposed of, re-labelling, re-processing for the quality improvement, or worst, the distributor or the importers will be prosecuted under the court action acts.

\section{Halal Assurance Management of Imported Food Product in Malaysia}

In Malaysia, the Department of Islamic Development Malaysia (JAKIM) is an agency under the Malaysian Prime Minister's Office that the Federal Government has mandated to process, verify and issue halal certificates and logos (Aziz N. A. et al. 2016, Rokshana, 2017). This includes all local or imported merchandise that acknowledges their products with halal status. As for now, the Malaysian Halal Certification Scheme is issued into nine categories; food products and beverages, food premises and hotels, cosmetics and personal care, consumer goods, slaughterhouse, pharmaceuticals, logistics, medical devices, and original equipment manufacturing (OEM) (MPPHM, 2020). Malaysian halal certification application is open to all interested and voluntary merchandise operators.

The halal certification certificate is issued to the applicant after passing all the Malaysian halal certification conditions and regulations. Each owner of this halal certification is bounded by the rules and laws that have been set in the Malaysian legislation, such as the Trade Descriptions Act 2011, Food Act 1983, or any related regulations (Rahman et al., 2018). In ensuring the halal assurance on imported food products, JAKIM has conducted a monitoring and enforcement system on the food products by monitored the recognized foreign halal certification bodies (Zaid et al., 2017). Thus, monitoring and enforcing halal certificates and validating the international halal logo is very important in the management process to ensure the imported foods that enter the country have a guaranteed halal status.

This halal assurance management covered the management and communication systems and involved the factors that affect the quality of management. Therefore, the management approach of an organization should always be holistic and comprehensive to ensure that imported food products that were entering the Malaysian market are always halal and safe to consume. 


\section{Types of Halal Imported Food Products}

As mention earlier, in Malaysia, the halal imported food products can be categorized as the products that used halal certification and logo from JAKIM or foreign halal certification bodies (FHCB) recognized by JAKIM (Zaid et al., 2017). According to the current FHCB (2020), there are 84 bodies recognized by JAKIM from 46 countries worldwide. Therefore, all these FHCBs can certify the imported food products and import them to the country.

\section{The Importation of Halal Imported Food Products under The Control of JAKIM and Trade Description Act 2011}

JAKIM has established a Procedures for Appointment of Foreign Halal Certification Bodies (JAKIM, 2017) to ensure halal assurance on the imported food products. The purpose of this procedure is to facilitate and conduct a monitoring process on foreign halal bodies that have been recognized to certified imported food products as halal in their own country. Therefore, once the imported food products entered the country, JAKIM will not monitor again because it has received confirmation from the recognized foreign halal certification bodies (Noor Azmi, 2015).

When the imported food products are certified with foreign halal certification bodies that JAKIM has not recognized, the products will not be allowed to enter Malaysia (Noor Azmi, 2015). Therefore, this circular also states that recognizing these foreign halal certification bodies ensures they perform their responsibilities by monitoring and enforcing the company that applied to them before they certified the products (JAKIM, 2017). In addition, this recognition also aims to encourage and help the company from a foreign country with halal certification on their product to market their products in Malaysia.

\section{Procedures on Monitoring and Enforcement as Halal Assurance Mechanism on Imported Food Products}

As stated, JAKIM does not have the authority and jurisdiction to monitor and control the imported food products that use halal certification from foreign halal certification bodies once the products have entered Malaysia (Noor Azmi, 2015). Therefore, one way to maintain the halal status of the imported food products is to impose a condition on these recognized foreign halal certification bodies to send a compliance audit report every two years to JAKIM (JAKIM, 2017). The aspects of compliance audit include aspects of human resources, a certification system, halal standards or halal guidelines, experts in shariah and technical, fatwa, sources of references, management and control of certification records, and conducting monitoring and enforcement (JAKIM, 2017).

In addition, JAKIM also conducts observational audits on slaughterhouses and factories or food processing plants to recognized overseas Islamic bodies (JAKIM, 2017). Once the compliance audit and observational audit have been done, the audit results' report will be presented to the halal certification panel board to get results. Then, if JAKIM approves the decision on the application for recognition, a letter of appointment will be given to the halal certification body, and the confirmation of the recognition of the halal certificate for the foreign halal body will continue. After that, JAKIM will upload a list of all overseas halal certificates recognized on the website.

An official letter will be issued informing the rejection and withdrawal of recognition for the application that failed for the audit results. For the Foreign halal certification body that fails to 
submit the compliance audit report, or JAKIM finds any doubt on the report submitted, JAKIM will send a two-week reminder notice to resubmit and revise the audit report (MPPHM, 2020). If the foreign halal body fails to submit the audit report within the times given, the halal recognition will automatically be withdrawn (Noor Azmi, 2015).

Furthermore, JAKIM has the right to announce the withdrawal of the halal recognition of the foreign halal body to the public. This ensures the industry in Malaysia and the consumer are aware of the latest recognition of halal certification bodies (Noor Azmi, 2015). However, the foreign halal certification bodies withdrawn may re-apply to obtain recognition after six months from the certification withdrawal (JAKIM, 2017). If the application has been fulfilled as stated in the requirements, JAKIM will again set up an audit of compliance for the application (JAKIM, 2017).

\section{A Halal Assurance on The Enforcement Actions}

In general, JAKIM/JAIN/MAIN imposed no specific enforcement action on imported food products that used foreign halal certification bodies unless there are complaints and doubts about the products (Mahmod, 2011). If the product violates the condition related to the halal matter, the inspection performed is almost the same as the enforcement inspection carried out on the local food products with JAKIM halal certification. For example, if the complaint relates to the ingredients, JAKIM will take a food sample for a laboratory test to the Department of Chemistry Malaysia. After obtaining the result and it violated the halal guidelines, JAKIM will take immediate enforcement action, and the certificate of recognition for the foreign halal body (FHCB) will be withdrawn from the JAKIM recognition list (Noor Azmi, 2015).

Notification of withdrawal of halal certificate recognition will be issued, and a letter will be notified to the relevant foreign halal certification body. As a result of the withdrawal, all related imported food products that use the same halal logo and certification from the accused's certification body will be blocked by the Royal Malaysian Customs Department and the Malaysian Quarantine and Inspection Services Department (MAQIS) at the national border. (Zaid et al., 2017).

For the products already in the market, the imported food products confirmed to have doubts and violate the prescribed halal circulars will be ordered to be removed by the batch codes on its entry numbers. However, the products that use different batch numbers will not be withdrawn. Besides, other imported food products used the same as the withdrawal foreign halal certification body on their products will also not be removed from the market (Noor Azmi, 2015). This is because only the confirmed products to have doubts and violate the prescribed halal circulars will be ordered to be removed.

\section{Prosecution Process}

Prosecution actions such as legal lawsuits will not be imposed on the recognized foreign halal certification bodies even if it violates the guidelines that have been set. This is due to the absence of specific laws or acts to bring legal action against the international halal certification body (Noor Azmi, 2015). In addition, the act in the Malaysian constitution is only subjected to matters related to Malaysian affairs and not to the international bodies (TDA, 2011). 
Volume 1 Issue 1 (September 2021) PP. 08-19 DOI 10.35631/IJHEMP.11002

\section{Analysis of Halal Assurance on Imported Food Products}

As mention in the importation of foods under the control of the Food Act 1983 and Food Regulations 1985, the importation of food in Malaysia is not explicitly stated towards halal matters but contributes to the safety aspect. But, if the imported food products are declared halal status by using the recognized foreign halal certification bodies and logo, halal assurance will be checked together while importation activities are carried out indirectly.

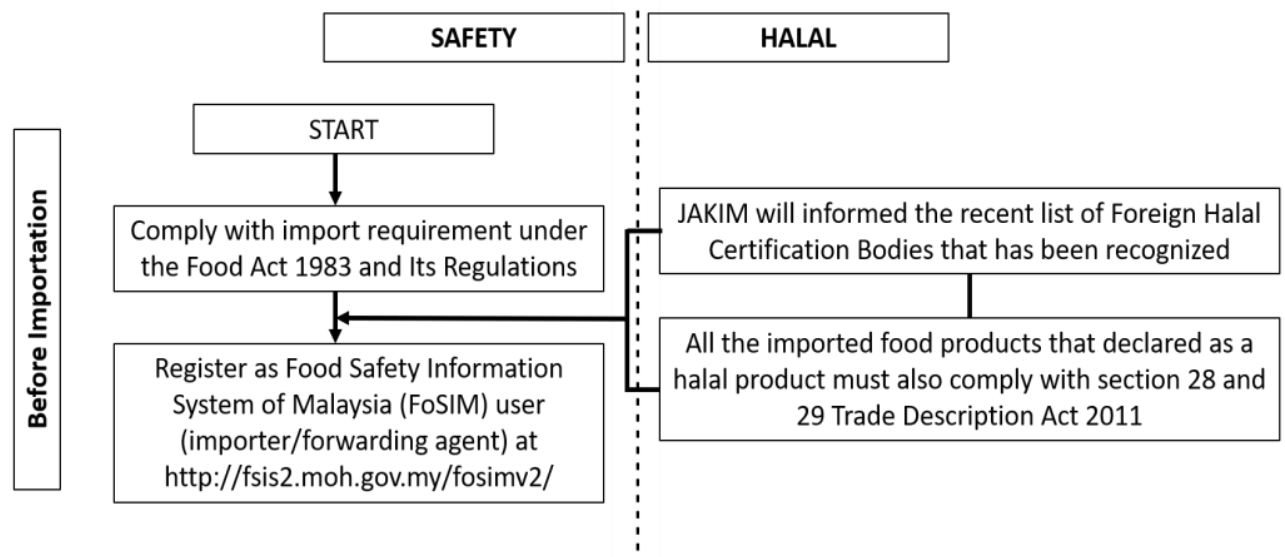

Figure 3: Flow Chart of Halal Food Import Procedures for Importers and Agents Source: (Noor Azmi 2015)

According to figure 3, before the entrance of the imported food products, JAKIM will inform Food Safety Information Management (FOSIM) under the Food Safety Quality Division about the latest recognition list of foreign halal certification bodies. This is to inform the Customs and MAQIS about the latest FHCB recognized by JAKIM. Thus, this also helps the Customs and MAQIS uphold a responsibility to accept or reject the declared halal imported food products at the country's entry.

For some issues, if the violation on halal occurred on the imported food products, it is considered to violate the Trade Description Act 2011 under section 28 and section 29; on orders for the issues of breaking the definition of halal and offence by using a fake halal logo and certification on the products. In addition, it can also be charged under Food Act 1983 and its regulations if it violated the orders related to food safety (Noor Azmi, 2015).

The actions will be taken by JAKIM and the prosecution by the Ministry of Domestic Trade and Consumer Affairs (KPDNHEP) regarding the violation made by the importers to ensure the halal assurance upon the imported food products. For example, if the food products contain nonhalal ingredients or are dubious, the affected products will be recalled by their brand and batch from the market. Besides, the foreign halal certification body that certified the product will be delisted from the JAKIM's recognition. Furthermore, the product's importer can also be charged under the Trade Description Act 2011. Then, JAKIM will announce or do public information about the affected product and the delisted halal bodies to the consumers (Noor Azmi, 2015). 


\section{The Effectiveness of Halal Assurance System on Imported Food Product}

There are fewer cases involved with the assurance system on the halalness of imported food products in Malaysia. According to a report released by MATRADE (2020), Malaysia's imports and exports are constantly increasing, showing that the imported products are in an effective managing system.

However, since last year, an issue arose on the imported meat cartel (Farhan et al., 2021), which caused questions on the effectiveness of the halal assurance system on the imported food products. To date, the investigation is still ongoing, and the latest information was this case claimed has to be happened for over the past 40 years (Rohiman, 2021). This shows the meat cartel issue is a serious offence, and it needs to be emphasized and reviewed by all parties.

Indeed, this meat fraud has fuelled anger among most Muslim populations and subsequently has shattered the Malaysian halal system (Richard W., 2021). Thus, the Malaysia Halal Council (MHC), JAKIM, and related authorities bodies have investigated these issues to ensure the halal assurance on this imported meat product is under control and hopes all parties refrain from speculating about the meat cartel case (NST, 2020). According to Z. Ruzulan et al. (2021) and Ravin P. (2021), within this case, there is a reasonable effort to establish a stand-alone halal law to cater for halal matters, and it definitely can improve the management system of halal assurance on the imported food product.

\section{Conclusion}

In conclusion, the implementation of halal assurance for imported food products, JAKIM, and other agencies such as the Food Safety Quality Division (FSQD), FOSIM, Customs, and MAQIS are working together to maintain the status of halal and safety of a product. This is due to the imported food product in Malaysia is voluntary and not mandatory. However, every food product declared with halal is subjected to the Trade Descriptions Act 2011, Food Act 1983 and its regulations, and Manual Procedure for Halal Certification (MPPHM). Furthermore, for the imported food products that used the International Halal logo and certification (FHCB), the halal logo and the halal certificate must be listed as the Certification Bodies (CB) list that JAKIM recognizes. Thus, if the imported food products or the importers violated these orders, they will be punished under the related rules. Therefore, these actions can be assured as a halal assurance system in maintaining the halal and safety aspects of the halal imported food products.

\section{References}

Azdee A. (2020, December 29). Jakim announces an action plan to tackle the meat cartel scandal. New Straits Times. https://www.nst.com.my/news/nation/2020/12/653040/jakim-announces-action-plantackle-meat-cartel-scandal.

Bernama. (2020, December 23). MAQIS needs more manpower to control goods entering country. The Sun Daily. https://www.thesundaily.my/local/maqis-needs-moremanpower-to-control-goods-entering-country-EF5610503.

Bernama. (2020, December 5). Johor government to discuss 'meat cartel' issue with relevant agencies-Exco. The Borneo Post. https://www.theborneopost.com/2020/12/05/johorgovernment-to-discuss-meat-cartel-issue-with-relevant-agencies-exco/. 
Volume 1 Issue 1 (September 2021) PP. 08-19 DOI 10.35631/IJHEMP.11002

Farhan. M., Nurul S., Fahmi M., Fareed A., Badlihisham. (2021). Halal Food Crime in Malaysia: An Analysis On Illegal Meat Cartel Issues. Journal of Contemporary Issues in Business and Government. Vol. 27, No. 2, 2021.

FHCB (2020). The Recognized Foreign Halal Certification Bodies and Authorities as at December $1^{\text {st }}$ 2020. Putrajaya: JAKIM.

FOSIM (2020). Registration of Importers and Shipping Agents for Food Importation, Offical Portal Food Safety Information System of Malaysia. Ministry of Health.

FSQD (2020). Food Importation, Official Portal of Food Safety Quality Division Malaysia. Ministry of Health.

JAKIM (2017). Procedures for Appointment of Foreign Halal Certification Bodies. Putrajaya: JAKIM

Mahmod, Z. (2011). Pelaksanaan Pemantauan dan Penguatkuasaan Undang-Undang Produk Halal di Malaysia: Kajian terhadap Penyalahgunaan Logo Halal. (Unpublished master dissertation) University of Malaya.

MATRADE (2020). Top 10 Import Major Product 2020. The Official Portal of Malaysia External Trade Development Corporation, The National Trade Promotion Agency of Malaysia.

MPPHM (2020). Manual Prosedur Pensijilan Halal Malaysia 2020. Putrajaya: JAKIM

Noor Azmi, M. T. (7 July 2015). Pengurusan Pemantauan dan Penguatkuasaan Halal di Malaysia. Interview Session. Putrajaya.

Aziz N.A., Ramli N., Raof N.A. (2016) JAKIM: Governors of Halal Affairs. In: Ab. Manan S., Abd Rahman F., Sahri M. (eds) Contemporary Issues and Development in the Global Halal Industry. Springer, Singapore

NST (2020, December 23). JAKIM appeals to all parties not to speculate on the 'meat cartel' issue.

New

Straits

Times. https://www.nst.com.my/news/nation/2020/12/651782/jakim-appeals-all-parties-notspeculate-meat-cartel-issue

Rahman, A.A, Md. Ismail, C.T. \& Abdullah, N.A. (2018). Regulating Halal Food Consumption: Malaysian Scenario. International Journal of Law, Government and Communication, 3 (13), 313-321.

Ravin P. (2021, January 4), Red meat sales drop in the supermarket after fake halal meat scandal. The Malaysian Insight. https://www.themalaysianinsight.com/s/293596

Richard W. (2021, January 4). Silence brings uncertainty for Malaysia's food industry amid the fake halal meat scandal. Salaam Gateway. https://salaamgateway.com/story/silence-brings-uncertainty-formalaysias-foodindustry-amid-fake-halal-meat-scandal

Rohiman. H. (2021, January 3). We're angry that the meat cartel has been operating for 40 years with impunity. New Straits Times. https://www.nst.com.my/opinion/columnists/2021/01/653978/were-angry-meat-cartelhas-been-operating-40-years-impunity

Rokshana S. A. (2017). Malaysian Halal Certification: Its Religion Significance and Economic Value. Shariah Journal, Vol. 25, No. 1 (2017) (pp. 137-156)

Sim L. L., Liew J. X., Aravinthan, R. (2020, December 3). Meat smuggling cartel busted in a raid. The Star. https://www.thestar.com.my/news/nation/2020/12/03/meat-smugglingcartel-busted-in-raid.

TDA (2011). Trade Description Act. Ministry of Domestic Trade and Consumer Affairs.

WITS (2018). Malaysia Trade Summary 2018 Data. World Integrated Trade Solution. 
Volume 1 Issue 1 (September 2021) PP. 08-19

DOI 10.35631/IJHEMP.11002

Ying, T. P. (2020, December 11). NGOs demand MACC probe meat cartel. News Straits Times. https://www.nst.com.my/news/nation/2020/12/648730/ngos-demand-macc-probemeat-cartel

Z. Ruzulan et al. (2021). Meat and meat-based products: Challenges and opportunities in halal. Food security. IOP Conf. Series: Earth and Environmental Science. 756 (2021) 012017.

Zaid M. D., Nurzahidah J., S. Fadylawati. (2017). Pemantauan dan penguatkuasaan halal terhadap produk makanan import oleh JAKIM. In M. F. P. Rameli, A. Q. Abdul Razak, M. T. Md Sharipp, M. Z. Mustafar, M. K. N. Mohd Aziz, N. Rawi, S. S. Suyurno, D. Sharif (Eds.), Proceeding of 2nd International Islamic Heritage Conference (ISHEC 2017) (pp. 527-545). Melaka: Academy of Contemporary Islamic Studies, Universiti Teknologi MARA. 